\title{
Gagasan Pembentukan Peradilan Khusus Pilkada Dalam Mewujudkan Electoral Justice
}

\author{
Surya Mukti Pratama (a), Ela Nurlela (b), Hendry Gian Dynantheo Sitepu (c)
}

(a) Fakultas Hukum Universitas Padjadjaran, surya17001@mail.unpad.ac.id

(b) Fakultas Hukum Universitas Padjadjaran, ela17001@mail.unpad.ac.id

(c) Fakultas Hukum Universitas Padjadjaran, giandynantheo@gmail.com

\begin{abstract}
General Election and Regional Election are two different things on a constitutional basis. Then it was strengthened and confirmed by the decision of the Constitutional Court No. 97 / PUU / XI / 2013. This condition encourages the author to discuss the urgency of establishing a special election court with a simultaneous regional election system and a special court format that is effective in realizing electoral justice. This article aims to discuss the problems faced in resolving regional election results disputes in order to realize electoral justice in regional elections. The juridical formation of a special regional elections judicial body is an urgent need because it is a mandate of the law that must be implemented. The regional elections court format in realizing electoral justice includes three important principles that must be possessed by the regional elections court, the status and position of the regional elections court, the regional elections court judges, the role of the Supreme Court as judex juris and is attributed the authority to review the decision of the regional elections special court and relate to absolute competence. from the regional elections court.

Keywords: Simultaneous Regional Elections; Election Result Dispute; Regional Elections Special Court; Electoral Justice.
\end{abstract}

\begin{abstract}
Abstrak
Pemilihan Umum dan Pemilihan kepala daerah adalah dua hal yang berbeda secara dasar konstitusional. Kemudian diperkuat dan dipertegas oleh putusan Mahkamah Konstitusi No 97/PUU/XI/2013. Permasalahan kewenangan Mahkamah Konstitusi menyelesaikan sengketa hasil pilkada tidak bisa dibiarkan sampai waktu yang lama. Karena pelaksanaan kewenangan transisional yang dibirakan menunjukan ketidaktaatan pemerintah dan DPR terhadap perintah undang-undang yang tidak dibenarkan dalam suatu negara hukum. Kondisi itu mendorong penulis membahas berkaitan dengan urgensi pembentukan peradilan khusus pilkada dengan sistem pilkada serentak serta format peradilan khusus yang efektif untuk mewujudkan electoral justice. Artikel ini bertujuan untuk mengatasi masalah yang dihadapi dalam penyelesaian sengketa hasil pilkada agar dapat mewujudkan electoral justice dalam pemilihan kepala daerah. Pembentukan badan peradilan khusus Pilkada secara yuridis menjadi kebutuhan yang bersifat urgensial karena merupakan suatu amanat dari undang-undang yang harus dilaksanakan. Pembentukan badan peradilan khusus ini juga penting karena dorongan kebutuhan praktis, yaitu pilkada diadakan serentak. Adapun format pengadilan pilkada dalam mewujudkan electoral justice meliputi tiga asas penting yang harus dimiliki pengadilan pilkada, status dan kedudukan pengadilan pilkada, hakim pengadilan pilkada, peran Mahkamah Agung sebagai judex juris dan diatribusikan kewenangan melakukan peninjauan kembali terhadap putusan pengadilan khusus pilkada serta berkaitan dengan kompetensi absolut dari pengadilan pilkada. Kata Kunci: Pilkada Serentak; Sengketa Hasil Pilkada; Peradilan Khusus Pilkada; Electoral Justice.
\end{abstract}

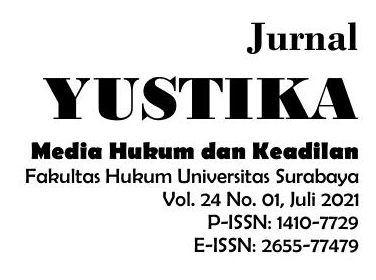


Jurnal Yustika

Vol. 24 No. 01, Jul 2021

Halaman | 15

Gagasan

Pembentukan

Peradilan Khusus

Pilkada Dalam

Mewujudkan Electoral Justice

Surya Mukti Pratama Ela Nurlela Hendry Gian Dynantheo S.

\section{Pendahuluan}

Pemilihan umum (Pemilu) dan Pemilihan Kepala Daerah (Pilkada) merupakan suatu perwujudan prinsip kedaulatan rakyat dan seyogyanya juga semakin mencerminkan proses kematangan berdemokrasi dalam suatu negara, (Nugroho, 2016) disamping menjadi sarana pelaksanaan hak asasi manusia utamanya hak memilih dan dipilih. Walaupun keduanya samasama merupakan bentuk wujud pelaksanaan intrumen demokrasi dan sarana pelaksanaan hak asasi, Pemilu dan Pilkada merupakan dua hal yang berbeda. Dasar konstitusional pelaksanaan Pilkada tidak terletak dalam Bab Pemilu, melainkan diatur dalam Bab tentang Pemerintah Daerah yaitu tepatnya dalam Pasal 18 ayat (4) yang menegasakan bahwa Gubernur, Bupati, dan Walikota masing-masing sebagai kepala pemerintah daerah provinsi, kabupaten dan kota dipilih secara demokratis.

Berdasarkan ketentuan di atas terlihat desain konstitusional menempatkan Pilkada merupakan bagian dari rezim pemerintah daerah, bukan rezim pemilu. Hal ini didukung oleh penafsiran sistematis terhadap Pasal 22 E UUD 1945, dimana setelah mengatur prinsip pemilu, dalam rumusan ayat (2) berturut-turut menyebut macam-macam bentuk pemilu, yaitu diselenggarakan untuk memilih anggota Dewan Perwakilan Rakyat, Dewan Perwakilan Daerah, Presiden dan wakil presiden dan Dewan Perwakilan Rakyat Daerah. Pilkada sama sekali tidak disebut dalam rumusan ayat tersebut. Pandangan hukum demikian diperkuat dan dipertegas oleh putusan Mahkamah Konstitusi No 97/PUU/XI/2013. Putusan ini membatalkan Pasal 236 C UU 12 Tahun 2008 tentang Pemerintah Daerah dan Pasal 29 ayat (1) huruf e UU 48 Tahun 2009 tentang Kekuasaan Kehakiman yang menjadi dasar kewenangan Mahkamah Konstitusi dalam memutus perselisihan hasil Pilkada.

Putusan Mahkamah Konstitusi 2013 tersebut, memiliki kesamaan pandangan dengan putusan Mahkamah Konstitusi terdahulu, yaitu No. 072-073/PUU-II/ 2005 tertanggal 22 Maret 2005. Dalam pertimbangan putusan tersebut, Mahkamah Konstitusi menyatakan: "Mahkamah berpendapat bahwa Pilkada langsung tidak termasuk dalam kategori Pemilu sebagaimana dimaksudkan Pasal 22 E UUD 1945. Namun demikian, Pilkada langsung adalah pemilihan umum secara materiil untuk mengimplementasikan Pasal 18 UUD 1945. Oleh karena itu, dalam penyelenggaraannya dapat berbeda dengan pemilu sebagaimana dimaksud dalam Pasal $22 \mathrm{E}$ UUD 1945, misalnya dalam hal regulator, penyelenggara, dan badan yang menyelesaikan perselisihan hasil Pilkada, meskipun harus tetap didasarkan atas asas-asas pemilihan umum yang berlaku." Namun demikian, dalam pelaksanaannya sampai hari ini baik Pemilu maupun Pilkada sama-sama dilaksanakan atau diselnggarakan oleh lembaga negara yang sama yaitu Komisi Pemilihan Umum (KPU).

Sebagai satu proses politik dalam praktiknya seringkali Pemilu termasuk juga Pilkada menghasilkan perselisihan atau sengketa baik itu menyangkut hasil dari Pemilu yang ditetapkan oleh lembaga penyelenggara ataupun sengketa yang timbul dalam kegiatan kampanye, ataupun teknis pelaksanaan pemungutan suara (Asshiddiqie, 2009). Kemungkinan tersebut bisa disebabkan oleh kecurangan (fraud), kekhilafan (mistake), maupun strategi pemenangan Pemilu yang tidak melanggar hukum tetapi menurunkan kepercayaan publik (non-fraudulent misconduct) (Gaffar, 2021). Penyelesaian sengketa tersebut tentunya harus dilaksanakan melalui cara-cara dan prosedur yang konstitusional, hal itu untuk menjamin tidak terjadinya chaos yang menggangu keberlangsungannya kehidupan ketatanegaraan dan penyelnggaraan pemerintahan. 
Undang-Undang Nomor 10 Tahun 2016 perubahan Kedua Atas Undang-Undang Nomor 1 Tahun 2015 tentang penetapan peraturan pemerintahan pengganti Undang-Undang Nomor 1 Tahun 2014 tentang pemilihan Gubernur, Bupati, Walikota mejadi Undang-Undang (untuk selanjutnya disebut UU Pilkada) telah mengatur cukup komprehensif mengenai proses penyelesaian sengketa baik itu menyangkut sengketa proses, sengketa hasil pilkada, termasuk telah mengatur lembaga mana yang memiliki kewenangan menyelesaikan sengketa tersebut.

Berdasarkan UU Pilkada diatur secara proporsional beberapa lembaga yang diberi kewenangan untuk mengatur penyelesaian sengketa pilkada. Untuk pelanggaran kode etik diselenggarakan oleh Dewan Kehormatan Pemilu (DKPP) (Lihat Pasal 137), adapun sengketa pelanggaran administasi pemilihan diselesaikan oleh KPU sesuai tingkatan, untuk sengketa antar peserta dan peserta dengan penyelenggara diakibatkan oleh dikeluarkanya keputusan KPU Kota/ kabupaten diselesaikan oleh Bawaslu Provinsi dan apabila tidak puas dapat mengajukan kepada PTUN (Lihat Pasal 153 dan 154). Adapun untuk tindak pidana pemilihan sebagai kejahatan atau pelanggaran diselesaikan oleh aparat penegak hukum dan pengadilan umum. Sedangkan untuk sengketa hasil diselesaikan oleh pengadilan khusus pilkada (Lihat Pasal 157).

Namun sayangnya, ketentuan dalam UU Pilkada ini belum secara tuntas dapat direalisasikan. Hal yang menjadi "pekerjaan rumah" paling besar bagi pemerintah dan DPR saat ini adalah menyangkut penyelesaian sengketa hasil Pilkada, sebab sampai hari ini keberadaan badan peradilan khusus pilkada belum terbentuk. Padahal keberadaanya penting terutama jika dikaitkan dengan adanya ketentuan Pasal 157 ayat 1 yang menegaskan "Perkara perselisihan hasil Permilihan diperiksa dan diadili oleh badan peradilan khusus".

Pembentukan badan peradilan khusus Pilkada secara yuridis menjadi kebutuhan yang bersifat urgensial selain karena merupakan suatu amanat dari undang-undang yang harus dilaksanakan, pembentukan badan peradilan khusus ini juga penting karena dorongan kebutuhan praktis yang kian mendesak terutama dengan adanya Pilkada yang bersifat serentak.

Memang exsisting kewenangan penyelesaian sengketa hasil Pilkada sementara dilaksanakan oleh Mahakamah Konstitusi sampai terbentuknya pengadilan khusus pilkada sebagaimana ditegaskan dalam Pasal 157 ayat (1) UU Pilkada, artinya walaupun belum dibentuk peradilan khusus pilkada sebenarnya tidak tejadi kekosongan mekanisme penyelesaian sengketa hasil pilkada. Namun sebagai pelaksanaan kewenangan yang transisional tidak bisa dibiarkan terlalu berlarut-larut sampai waktu yang lama. Karena jika dibirakan, hal tersebut secara tidak langsung akan menunjukan ketidaktaatan atau ketidakpatuhan pemerintah dan DPR terhadap perintah undang-undang, dan itu merupakan hal yang tidak dibenarkan dalam suatu negara hukum.

Selain hal diatas, membiarkan Mahkamah Kontitusi (MK) terlalu lama melaksanakan kewenangan transisi akan sangat berpotensi memecah fokus Mahkamah Konstitusi dalam melaksanakan kewenangan asli yang diatribusikan oleh UUD utamanya dalam pengujian kontitusionalitas undang-undang (Mirza dkk, 2019).

Berdasarkan data dari MK pada tahun 2015 saja sengketa perselisihan hasil Pilkada mencapai 152 perkara dari total 269 daerah yang menggelar pilkada, begitupun taun 2017 terdapat 60 permohonan perselisihan hasil pilkada dari total 101 daerah yang melaksanakan Pilkada. Artinya lebih dari 50\% penyelenggaran pilkada berujung pada gugatan di MK (Nurhalimah, 2017) apalagi jika dalam waktu kedepan dengan pelaksanaan pilkada serentak 
Jurnal Yustika

Vol. 24 No. 01, Jul 2021

Halaman | 17

Gagasan

Pembentukan

Peradilan Khusus

Pilkada Dalam

Mewujudkan

Electoral Justice

Surya Mukti Pratama

Ela Nurlela

Hendry Gian Dynantheo S dimana jumlah daerah yang menyelenggarakan jauh lebih banyak, tentu akan lebih banyak pula jumlah perselisihan hasil pilkada yang muncul. Melihat jumlah perkara pemilu dan pilkada yang ditangani MK lebih banyak dari perkara pengujian UU, Jika demikian maka akhirnya MK cenderung berubah menjadi mahkamah sengketa pemilu (election court) (Anggono, 2016).

Hal yang dikemukan diatas terbukti misalnya dari pernyataan hakim MK Arif hidayat, yang menegaskan bahwa sengketa hasil pilkada yang sampai saat ini ditangani MK menjadi faktor yang memperlambat penyelesaian uji materi undang-undang (Fachrudin, 2017). Tentu hal ini tidak boleh dibiarkan mengingat sejatinya tugas utama Mahkamah Konstitusi sebagai the guardion of the constitution dan perkara pengujian undang-undang merupakan hal yang sangat penting karena sangat berkaitan dengan tertib norma perundang-undangan dan perlindungan hak asasi manusia yang menjadi pilar negara hukum.

Menurut penulis, pembentukan peradilan khsusus sangat diperlukan untuk kepentingan penyelengaraan pemerintahan daerah. Sebab tentunya jika penyelesaian sengketa hasil Pilkada - diselesaikan oleh satu badan yaitu Mahkamah Konstitusi untuk seluruh Pilkada di Indonesia, hal ini memperlambat penyelesaian sengketa. Dengan lamanya waktu tesebut maka secara tidak langsung akan menghambat penunjukan kepala daerah yang definitf kemudian pada akhirnya akan berdampak pada jalannya roda pemerintahan daerah.

Berdasarakan hal di atas, sudah saatnyaa menjadi perhatian serius pemerintah dan DPR untuk membentuk peradilan khusus yang menangani sengketa hasil Pilkada. Pembentukan pengadilan khusus tersebut haruslah dibentuk berdasarkan suatu dasar hukum berbentuk (kenvorm) undang-undang sebagaimana persyaratkan oleh Undang-Undang Nomor 48 tahun 2009 tentang Kekuasaan Kehakiman.

Kondisi di atas itulah yang mendorong penulis untuk melakukan penelitian yang pada fokusnya berusaha untuk menjawab dua pertanyaan besar berkaitan dengan bagaimanakah urgensi pembentukan Peradilan Khusus Pilkada dengan sistem Pilkada serentak? serta bagimana format Peradilan Khusus yang efektif untuk mewujudkan Pilkada serentak yang berparadigma electoral justice?

\section{Pembahasan}

\subsection{Urgensi Pembentukan Peradilan Khusus Pilkada Dalam Sistem Pilkada Serentak}

Pemilihan Kepala Daerah secara demokratis menjadi hal sangat penting dalam menjamin demokrasi dan keberlangsungan pemerintah daerah otonom. Maka demi memastikan tercapainya hal tersebut, proses Pilkada harus dilaksanakan secara adil. Pengadilan Pilkada adalah badan peradilan yang secara khusus hadir memastikan dan mengadili dalam hal terjadinya perselisihan hasil antara peserta pilkada.

Sebagai pengadilan, Pengadilan Pilkada merupakan representasi dari access to justice bagi masyarakat, khususnya bagi peserta Pilkada. Hal ini sebagaimana diamanatkan melalui Pasal 28D ayat (1) UUD 1945 bahwa setiap orang berhak atas pengakuan, jaminan, perlindungan, dan kepastian hukum yang adil serta perlakuan yang sama dihadapan hukum. Kehadiran Pengadilan Pilkada harus mampu memberikan rasa keadilan di masyarakat. Peserta pilkada (calon kepala daerah) juga adalah masyarakat, jika kemudian terjadi pelanggaran ataupun hal lainnya yang menciderai keadilan sehingga mengakibatkan timbulnya sengketa hasil antara peserta pilkada, hal ini harus dapat diatasi melalui Pengadilan Pilkada berdasarkan ketentuan Pasal 28D ayat (3) UUD 1945 yakni setiap warga negara memiliki kesempatan yang sama dalam 
pemerintahan. Maka dari itu, demi menjamin keadilan dan kepastian hukum dalam kontestasi Pilkada, perlu dibentuk suatu Pengadilan Pilkada.

Jurnal Yustika

Dalam UU Pilkada berdasar pada Pasal 157 ayat (1-3) yang menyebutkan bahwa, Perkara perselisihan hasil Pemilihan diperiksa dan diadili oleh badan peradilan khusus; Badan peradilan khusus sebagaimana dimaksud pada ayat (1) dibentuk sebelum pelaksanaan Pemilihan serentak nasional. Sayangnya sampai saat ini keberdaannya belum terealisasi. Padahal keberadaan Peradilan Khusus Pilkada di Indonesia menjadi suatu cita hukum yang ditujukan untuk melindungi hak konstitusional warga negara dan peserta pemilihan itu sendiri.

Pembentukan badan peradilan pilkada yang merupakan peradilan khusus ini mau tidak mau perlu dilembagakan di bawah sistem kekuasaan Mahkamah Agung (MA) yang diatur dalam suatu undang-undang, karena dalam konteks peradilan khusus, Pasal 1 angka 8 UU Kekuasaan Kehakiman menentukan bahwa "Pengadilan khusus adalah pengadilan yang mempunyai kewenangan untuk memeriksa, mengadili dan memutus perkara tertentu yang hanya dapat dibentuk dalam salah satu lingkungan badan peradilan yang berada di bawah MA.

Secara yuridis pembentukan peradilan pilkada ini memiliki landasan yang sangat legalrasional. Kontestasi politik di Indonesia merupakan suatu kebiasaan yang menjadi konsekuensi dari demokrasi. Seiring dengan perkembangannya, tentu pelaksanaan Pilkada akan selalu mengalami proses penyempurnaan. Jika didasarkan pada kerangka pikir Electoral Justice System, kehadiran Pengadilan Khusus Pilkada merupakan suatu penyempurnaan penyelenggaraan pemilu yang berkeadilan dalam wujud sistem penyelesaian sengketa pemilu.

Sebagaimana diamanatkan melalui Pasal 157 UU Pilkada akan keberadaan suatu badan peradilan khusus untuk memeriksa dan mengadili perkara hasil pemilihan Pilkada. Sejak saat dibentuknya ketentuan tersebut, belum ada perwujudan badan peradilan khusus yang dicitacitakan tersebut. Hal ini menjadi suatu permasalahan hukum, sejumlah peraturan perundangundangan lain yang tersedia menjadi dasar yang legitimate atas suatu kehadiran badan peradilan khusus sebagai cita hukum itu, namun hingga kini tidak dijumpai kejelasan mengenai seperti apa seharusnya badan peradilan khusus tersebut dalam mengatasi sengketa pilkada.

Pembentukan pengadilan pilkada juga secara konsekuen akan mencabut kewenangan dari MK, hal ini menjadi sejalan dengan Putusan MK No. 97/PUU-XI/2013 bahwa kewenangan penyelesaian sengketa hasil pilkada bukan kewenangan MK karena original intent dari Pemilu dalam Pasal 22E UUD 1945 tidak mencakup pemilihan kepala daerah. Putusan tersebut menjadi suatu urgensi untuk dilakukannya suatu reform dalam sistem pilkada di Indonesia yang secara langsung menjadi bukti bahwa adanya legal importance untuk membentuk sebuah pengadilan khusus yang secara spesifik menangani sengketa Pilkada (Wicaksono, 2015).

Memahami betapa pentingnya kehadiran pengadilan pilkada dalam kontestasi politik yang secara rutin diselenggarakan menjadi bukti daya laku (geltung) mengapa undang-undang pengadilan pilkada ini diperlukan dan keabsahan dari norma-norma yang akan menjadi materi muatan perundang-undangan ini nantinya. Pembentuk undang-undang dalam membentuk hukum atau mengadakan suatu institusi negara sepanjang tidak bertentangan dan menyimpang dari ketentuan konstitusi. Masalahnya adalah bagaimana bentuk dan posisi pengadilan khusus itu, sehingga tidak menyimpang atau tidak bertentangan dengan prinsipprinsip konstitusi (Zoelva, 2013).

\section{Vol. 24 No. 01, Jul 202 \\ Halaman | 18 \\ Gagasan \\ Pembentukan \\ Peradilan Khusus \\ Pilkada Dalam \\ Mewujudkan \\ Electoral Justice}

Surya Mukti Pratama

Ela Nurlela

Hendry Gian Dynantheo S. 
Jurnal Yustika

Vol. 24 No. 01, Jul 2021

Halaman | 19

Gagasan

Pembentukan

Peradilan Khusus

Pilkada Dalam

Mewujudkan

Electoral Justice

Surya Mukti Pratama

Ela Nurlela

Hendry Gian Dynantheo S.
Secara sosoligis tentu pembentukan peradilan pilkada ini juga dapat diterima secara terbuka karena pertimbangan yang rasional dan berdasar. Penyelesian sengketa hasil di MK memang telah dilaksanakan berdasarkan asas speedy trial (peradilan yang cepat), namun jika MK menjalankan kewenangan transisional ini dalam waktu yang lama, jelas akan menimbulkan persoalan "kesiapan" hakim MK yang hanya berjumlah 9 orang harus menangani Pilkada yang dalam waktu kedepan dilaksanakan dengan waktu yang serentak di seluruh wilayah Indonesia, disamping kerja MK untuk mengadili perkara lain terutama pengujian undang-undang sebagai kewenangan kontitusional yang tidak bisa dikesampingkan karena menyangkut tertib hukum dan hak asasi manusia.

Maka tak heran, dalam perkara perselisihan hasil Pilkada, MK tidak terlalu banyak mau masuk dalam pemeriksaan yang bersifat substantif dan lebih berpegang dalam keadilan prosedural. Contohnya pada Pilkda Serentak 2017, MK menerima 53 permohonan PHPU Kepala Daerah (PHPU.D). Namun hanya 3 permohonan yang dikabulkan sebagian. Sedangkan 42 permohoan tidak dapat diterima, 4 permohonan ditolak, 2 perintah pemungutan suara ulang dan 1 rekapitulasi penghitungan suara lanjutan.

Oleh sebab itu pembentukan peradilan pilkada sangat mendesak secara sosiologis karena kebutuhan masyarakat akan mekanisme penyelesian sengketa hasil pilkada yang efektif, dimana peradilan dilakukan secara cepat (speedy trial), namun tanpa mengabaikan kualitas proses pemeriksaan sehingga tercapainya kedilan procedural dan keadilan substntif, yang hal itu tidak mungkin bisa diabaikan dalam negara demokrasi konstitusional.

Dari segi penegakan hukum, konsistensi dari tindakan suatu lembaga sangat menentukan kadar kepastian hukum yang tercipta, dalam hal ini pengadilan pilkada. Artinya, bahwa dalam pelaksanaan kewenangan yang diberikan kepada pengadilan pilkada tersebut, konsistensi penerapan aturan perundang-undangan menjadi menentukan bagi terciptanya kepastian hukum.

\subsection{Format Pengadilan Pilkada Yang Efektif Dalam Mewujudkan Electoral Justice}

Sebagaimana diketahui bahwa dalam rangka mewujudkan Pilkada berkeadilan atau electoral justice yang menjadi ukuran keadilan adalah pada terdapatnya instrumen hukum Pemilu dan mekanisme penyelesaian masalah hukum Pemilu yang terjadi agar dapat melindungi hak pilih warga negara yang juga merupakan bagian dari hak asasi manusia (Santoso dkk, 2006). Mekanisme penyelesain sengketa hasil yang efektif dapat dilakukan melalui badan pengadilan yang dibentuk secara khusus untuk menyelesaikan sengketa hasil pilkada.

Apabila melihat praktik pengadilan pilkada di luar mislanya Brazil. Brazil memiliki sistem pemilihan umum dan penyelesaian sengketa yang termasuk paling efektif di dunia (IFES, 2011). Brazil memiliki dua jenis pemilu, yaitu Pemilu di tingkat negara federal dan Pemilu di tingkat negara bagian. Meskipun memiliki sistem pemilu yang berbeda, Indonesia dan Brazil sama-sama menganut sistem multipartai yang jelas berpengaruh pada jalannya Pemilu (Wicaksono, 2015). Pengadilan Pemilu di Brazil merupakan bagian dari Electoral Justice System, yaitu ( Lihat Article 118, Constitution of Brazil 1988) :
a. Superior Electoral Tribunal;
b. Regional Electoral Tribunal;
c. Electoral Jugdes; dan
d. Electoral Boards. 
Keanggotan Superior Electoral Court (SEC) terdiri dari 7 (tujuh) hakim, yang diangkat melalui pemilihan secara rahasia dan penunjukkan oleh Presiden (Bisariyadi dkk, 2016). Putusan Superior Electoral Tribunal tidak dapat diajukan banding, sehingga bersifat final dan mengikat. (Lihat Article 20, Constitution of Brazil 1988). Selanjutnya negara yang juga memiliki pengadilan pilkada yaitu Uruguay. Uruguay memiliki undang-undang Electoral Law 1924 yang menandai terbentuknya manajemen pemilu yang otonom dan mandiri, yang hampir selama satu abad sebelumnya berada di tangan kekuasaan Eksekutif hingga akhirnya dibentuk yurisdiksi Corte Electoral atau Electoral Court (Pengadilan Pemilu) yang independen dan permanen dan diatur kewenangannya secara langsung dalam Konstitusi (Wicaksono, 2015).

Uruguay dan Indonesia memiliki beberapa kesamaan karakter, keduanya sama-sama menganut sistem multipartai. Mekanisme Pemilu di Uruguay dilakukan bertingkat sesuai wilayah, yakni Pemilu di tingkat negara dan Pemilu di tingkat departemental atau provinsi, ekuivalen dengan Pemilu di tingkat Nasional dan Pilkada di Indonesia (Wicaksono, 2015). Pengadilan Pemilu Uruguay merupakan badan peradilan yang permanen, dan terbagi di tingkat nasional dan di tingkat daerah. Pengadilan Pemilu di tingkat nasional dikenal sebagai Corte Electoral, dan di tingkat daerah dikenal dengan Juntas Electorales. Kewenangan dari Pengadilan Pemilu Uruguay mencakup pada 3 hal, yakni:

a. Bertanggung jawab membuat peraturan pemilu dan mengawasi pelaksanaannya;

b. Menjadi pusat koordinasi segala hal terkait pemilu termasuk mengenai pembiayaan pemilu; dan

c. Memutus sengketa hasil pemilu.

Dapat dipahami bahwa kewenangan Pengadilan Pemilu di Uruguay sangat luas dan mencakup berbagai hal mulai dari pembuatan regulasi, perencanaan, pelaksanaan, hingga penyelesaian sengketanya. Hal tersebut kemudian menjadikan Pengadilan Pemilu Uruguay diistilahkan sebagai cabang kekuasaan ke-empat negara karena mampu mengambil alih fungsi eksekutif, legislatif, dan yudikatif (Wicaksono, 2015).

Pembentukan peradilan pilkada di Indonesia juga tentunya perlu didesain dengan format pengadilan yang efektif. Mengingat pilkada ini berjalan dan berlangsung tidak secara terus-menerus melainkan agenda politik yang dilaksanakan 5 tahun sekali. Format pengadilan pilkada yang dimaksud penulis adalah berkiatan dengan asas-asas yang harus dianut pengadilan pilkada dan berkaiatan dengan susunan pengadilan pilkada yang akan dibentuk.

Untuk dapat mewujudkan electoral justice ini pengadilan pilkada harus menganut dan didasari setidaknya oleh tiga asas-asas penting. Pertama, asas peradilan cepat. Kedua, Asas independensi peradilan. Ketiga asas jujur dan adil. Pertama, Prinsip independensi peradilan merupakan asas yang berlaku secara universal dalam negara hukum modern. Tak ada satu negara demokrasi tanpa keberadaan kekuasaan kehakiman yang merdeka. Bentuk dari independensi peradilan dapat dilihat dari dua aspek, yaitu independensi personal hakim dan independensi institusional (Komisi Yudisial, 2013).

Keith Rosenn, sebagaimana dikutip oleh Susi Dwi Harijanti, mengemukakan bahwa, "the degree to which judges actually decides cases inaccordance with their own determination of the evidence, the law and justice, free from the coercion, blandishment, interference, orthreats from governmental authorities or private citizens" (Azhar, 2018). Dalam konteks pengadilan pilkada hal itu tentu menjadi sangat penting terutama karena keputusan pilkada akan berkahir dengan penunjukan kepala daerah yang perlu benar-benar legitimate menurut hukum. 
Jurnal Yustika

Vol. 24 No. 01, Jul 2021

Halaman | 21

Gagasan

Pembentukan

Peradilan Khusus

Pilkada Dalam

Mewujudkan

Electoral Justice

Surya Mukti Pratama

Ela Nurlela

Hendry Gian Dynantheo S.
Kontekstualisasinya Jika sebuah badan peradilan menganut prinsip independen (tidak memihak dan merdeka) dalam melaksanakan fungsi adjudicative-nya, maka badan tersebut harus memiliki kewenangan khusus yang tetap membuatnya "terpisah" dari cabang kekuasaan lain terutama institusi ke pemerintahan, organisasi politik, pengaruh organisasi nongovernmental, dan terbebas dari pengaruh-pengaruh lain di luar itu (Enggarani, 2018). Oleh sebab itu dalam pandangan penulis peradilan Pilkada ini harus berada dibawah cabang kekuasan kehakiman, diman Mahkamah Agung (MA) sebagai puncak tertingginya.

Kedua, Asas perdilan cepat (speedy trial) ini dimaksudkan untuk dapat meringankan biaya persidangan dan disisi lain dapat juga mereduksi konflik yang akan berkepanjangan dari suatu kasus (Suhendra, 2019). Menurut Jimly Ashshiddiqie sudah seharusnya dalam urusan kepemiluan perkara-perkara yang terkait dengan penanganan pelanggaran pemilu membutuhkan kepastian dalam mekanisme penyelesaiannya, berupa jadwal waktu, sehingga peradilan dalam urusan kepemiluan (electoral justice) harus dipandang sebagai salah satu bentuk atau jenis peradilan cepat (speedy trial) (Minan dkk, 2019).

Selaian pembatasan pada waktu berperkara, prinsip peradilan cepat ini harus tercermin juga dari putusan pengadilan pilkada, yang harus didesain sebagai putusan yang bersifat final dan binding. Kewenangan kasasi tidak perlu diberikan kepada MA karena selain substansinya sama antara PK dan Kasasi, hal ini pun akan mendukung pelaksanaan asas peradilan cepat (speedy trial). Pemberian kewenangan kepada MA hanya untuk melakukan PK terhadap putusan pengadilan pilkada ini selaras dan sejalan dengan norma hukum dalam putusan Mahkamah Kontitusi pada Perkara Nomor 004/PUU-II/2004, bahwa keberadaan upaya hukum PK dan pembinaan teknis peradilan bagi Pengadilan khusus yang dilakukan oleh MA, telah cukup menjadi dasar bahwa suatu Pengadilan termasuk dalam lingkup peradilan yang berada di bawah MA sebagaimana dinyatakan oleh Pasal 24 ayat (2) UUD 1945.

Kemudian format pengadilan yang dimaksud penulis selanjutnya adalah berkiatan dengan kedudukan dan susunan badan peradilan Pilkada. Hemat penulis Peradilan Pilkada harus didesain sebagai badan pengadilan ad-hoc, dengan kedudukan berada pada setiap Pengadilan Tinggi Tata Usaha Negara. Kendudukan pengadilan pada PT. TUN tersebut ditujukan untuk mampu mengatasi permasalahan yang selama ini timbul, selama kewenangan mengadili masih ada pada MK, terutama berkaiatn dengan kontsitusionalitas dan aksesibilitasnya. Tidak hanya itu, membentuk pengadilan pilkada pada PT. TUN yang ada juga ditujukan sebagai upaya membatasi tekanan-tekanan sosiologis yang seringkali dialami pengadilan dan hakim, khususnya oleh kepentingan politik para peserta pilkada. Sehingga melalui mekanisme ini, access to justice dapat tetap terakomodir, sekaligus membatasi intimidasi sosiologis yang sering dialami pengadilan di daerah.

Selanjutnya berkaitan dengan hakim, menurut penulis Pengadilan Pilkada dapat didesain memiliki 2 status hakim seperti lazimnya suatu pengadilan ad-hoc, yaitu hakim karir dan hakim non-karir. Sebagai pengadilan ad hoc, maka hakim Pengadilan Pilkada baik hakim karier maupun hakim non-karier dipilih sebagai hakim ad hoc. Hal ini ditujukan untuk mengakomodir pelaksanaan Pilkada serentak, dimana pelaksanaan Pilkada akan dilaksanakan secara bersama-sama di setiap daerah, maka pengadilan dibentuk secara ad hoc yakni 5 tahun sekali untuk menjamin efisiensi pengadilan. Hakim pengadilan pilkada akan dipilih melalui seleksi. Seleksi tersebut akan diselenggarakan oleh Panitia Seleksi (Pansel) yang ditunjuk dan dibentuk oleh MA. 
Pelibatan MA dalam penentuan susunan hakim pengadilan pilkada dan teknis pengadilan menjadi hal yang penting. Peran MA sebagai puncak tertinggi badan peradilan, yang selain berperan dalam pembinaan teknis peradilan seperti pengisian jabatan hakim pada pengadilan khusus pilkada juga harus memiliki peran judex juris sebagai upaya kontrol terhadap fungsi yudisial badan peradilan di bawahnya. MA harus diatribusikan kewenangan melakukan peninjuan kembali (PK) terhadap putusan pengadilan khusus Pilkada. Kewenangan kasasi tidak perlu diberikan kepada MA karena selain substansinya sama antara PK dan Kasasi, hal ini pun akan mendukung pelaksanaan asas peradilan cepat (speedy trial). Pemberian kewenangan kepada MA hanya untuk melakukan PK terhadap putusan pengadilan pilkada ini selaras dan sejalan dengan norma hukum dalam putusan Mahkamah Kontitusi pada Perkara Nomor 004/PUU-II/2004, bahwa keberdaan upaya hukum PK dan pembinaan teknis peradilan bagi pengadilan khusus yang dilakukan oleh MA, telah cukup menjadi dasar bahwa suatu pengadilan termasuk dalam lingkup peradilan yang berada di bawah MA sebagaimana dinyatakan oleh Pasal 24 ayat (2) UUD 1945.

Format terkahir adalah berkaitan dengan kompetensi absolut dari pengadilan pilkada. Kompetensi absolut suatu badan pengadilan adalah kewenangan yang berkaitan untuk mengadili suatu perkara menurut obyek atau materi atau pokok sengketa. Pengadilan pilkada memiliki kewenangan untuk memeriksa, mengadili dan memutus perkara dalam lingkup sengketa atas perselisihan hasil Pilkada. Sengketa perselisihan hasil pilkada yang dimaksud mengacu pada UU Pilkada, yaitu perselisihan antara peserta Pilkada dan KPU sebagai penyelenggara pemilu mengenai penetapan perolehan suara hasil pilkada oleh KPU (Surbakti, 2011). Sehingga objektum litis/ objek sengketa pada pengadilan Pilkada adalah terbatas pada keputusan KPU Provinsi dan KPU Kota/Kabupaten tentang penetapan hasil perolehan suara Pilkada. Adapun pemohon dalam sengketa ini adalah peserta pilkada, dan KPU sebagai termohon.

\section{Kesimpulan}

Urgensi peradilan khusus pemilihan kepala daerah adalah suatu amanat dari undangundang yang harus dilaksanakan yang telah diatur dalam Undang-Undang Republik Indonesia Nomor 10 Tahun 2016 perubahan kedua atas Undang-Undang Nomor 1 Tahun 2015. Pembentukan badan peradilan khusus ini juga penting karena dorongan kebutuhan praktis, yaitu Pilkada diadakan serentak. Adanya peradilan pilkada bukan sesuatu yang baru, karena di Brazil dan Uruguay yang sama seperti Indonesia menganut sistem multipartai pun telah terlebih dahulu memiliki peradilan pilkada yang terbukti berhasil menangani penyelesaian pilkada secara efektif. Indonesia sudah seharusnya membentuk peradilan pilkada untuk mengimbangi pilkada serentak guna penyelesaian sengketa pilkada yang dapat mewujukan electoral justice.

Format pengadilan pilkada dalam mewujudkan electoral justice, yaitu pengadilan pilkada menganut dan berdasar pada tiga asas-asas penting, yaitu asas peradilan cepat, asas independensi peradilan, asas jujur dan adil. Kemudian peradilan pilkada didesain sebagai badan pengadilan ad-hoc, dengan kedudukan berada pada setiap Pengadilan Tinggi Tata Usaha Negara. Selanjutnya penulis juga berpendapat bahwa hakim pengadilan pilkada didesain memiliki 2 status hakim seperti lazimnya suatu pengadilan ad-hoc, yaitu hakim karir dan 
Jurnal Yustika

Vol. 24 No. 01, Jul 2021

Halaman | 23

Gagasan

Pembentukan

Peradilan Khusus

Pilkada Dalam

Mewujudkan Electoral Justice

Surya Mukti Pratama

Ela Nurlela

Hendry Gian Dynantheo S.

hakim non-karir. Dalam hal ini MA juga dilibatkan untuk menentukan susunan hakim pengadilan pilkada dan teknis pengadilan. Selain itu MA memiliki peran judex juris dan MA diatribusikan kewenangan melakukan PK terhadap putusan pengadilan khusus Pilkada. Terakhir, pengadilan pilkada memiliki kewenangan untuk memeriksa, mengadili dan memutus perkara dalam lingkup sengketa atas perselisihan hasil Pilkada.

\section{Daftar Referensi}

Buku

Ahsanul Minan dkk. (2019). Perihal Penegakan Hukum Pemilu. Jakarta: Bawaslu.

IFES. (2011). Pedoman untuk Memahami, Menangani, dan Menyelesaikan Sengketa Pemilu, Washington DC: IFES.

Jimly Asshiddiqie. (2009). Pengantar Ilmu Hukum Tata Negara. Jakarta: PT Raja Grafindo.

Komisi Yudisial. (2013). Putih Hitam Pengadilan Khusus. Jakarta : Pusat Analisis Dan Layanan Informasi Sekretariat Jendral Komisi Yudisial.

Ramlan Surbakti, dkk. (2011), Penanganan Sengketa Pemilu, Seri Demokrasi Elektoral Buku 16, Jakarta Selatan : Kemitraan Partnership.

Topo Santoso dkk. (2006). Penegakan Hukum Pemilu: Praktik Pemilu 2004, Kajian Pemilu 2009-2014. Jakarta : Perludem.

Artikel Jurnal

Ahmad Mirza dkk. (2019). Pergeseran Rezim Sistem Pemilihan Kepala Daerah Di Indonesia. Kanun Jurnal Ilmu Hukum Volume 21 Nomor 3. https://doi.org/10.24815/kanun.v2li3.12231

Bayu Dwi Anggono. (2016). Pembatasan Pengajuan Perkara Sengketa Hasil Pemilihan Kepala Daerah Di Mahkamah Konstitusi Dan Implikasinya Terhadap Jaminan Keamanan Nasional. Jurnal Rechts Vinding Media Pembinaan Hukum Nasional Volume 5 Nomor 1

Bisariyadi, Anna Triningsih, and Meyrinda Rahmawaty. (2016). Komparasi Mekanisme Penyelesaian Sengketa Pemilu di Beberapa Negara Penganut Paham Demokrasi Konstitusional. Jurnal Konstitusi Volume 9 Nomor 3

Dian Agung Wicaksono dan Ola Anisa Ayutama. (2015). Inisiasi Pengadilan Khusus Pemilihan Kepala Daerah Dalam Menghadapi Keserentakan Pemilihan Gubernur, Bupati, Dan Walikota Di Indonesia 1. Jurnal Rechts Vinding: Media Pembinaan Hukum Nasional Volume 4 Nomor 1

Hamdan Zoelva. (2013). Problematika Penyelesaian Sengketa Hasil Pemilukada oleh Mahkamah Konstitusi. Jurnal Konstitusi Volume 10 Nomor 3

Ikhsan Azhar. (2018). Inkonsistensi Penerapan Prinsip Independensi Kekuasaan Kehakiman Dalam Pelaksanaan Seleksi Calon Hakim. Jurnal VeJ Volume 4 Nomor 2. https://doi.org/10.25123/vej.v4i2.3070

Nuria Siswi Enggarani. (2018). Independensi Peradilan Dan Negara Hukum. Jurnal Law and Justice Volume 3 Nomor 2. https://doi.org/10.23917/laj.v3i2.7426

Siti Nurhalimah. (2017). Pembentukan Peradilan khsuus Pilkada. Buletin Hukum dan Keadilan Volume 1 Nomor $5 c$

Tri Suhendra Arbani. (2019). Pemenuhan Unsur Keadilan Dalam Pembuktian Perselisihan Hasil Pemilihan Umum Pilpres Dengan Konsep Spedy Trial. Journal KPU.

Wahyu Nugroho. (2016). Politik Hukum Pasca Putusan Mahkamah Konstitusi atas Pelaksanaan Pemilu dan Pemilukada di Indonesia. Jurnal Konstitusi Volume 13 Nomor 3. https://doi.org/10.31078/jk.1331

Artikel Internet 
Fachri Fachrudin. (2017). Masih Tangani Sengketa Pilkada, MK Terhambat dalam Uji Materi. https://nasional.kompas.com/read/2017/03/09/23175681/masih.tangani.sengketa.pilkada.mk.terham bat.dalam.uji.materi. (Diakses pada 30 September 2020).

J.M Gaffar. (2021). Lembaga Peradilan Pemilu. http://nasional.sindonews.com/read/673846/18/lembagaperadilan-pemilu-1348179513, (Diakses pada 19 Oktober 2020).

\begin{tabular}{r} 
Jurnal Yustika \\
Vol. 24 No. 01, Jul 2021 \\
\hline Halaman I 24 \\
Gagasan \\
Pembentukan \\
Peradilan Khusus \\
Pilkada Dalam \\
Mewujudkan \\
Electoral Justice \\
Surya Mukti Pratama \\
Ela Nurlela \\
Hendry Gian Dynantheo S.
\end{tabular}

